\title{
PETROLOGY, GEOCHEMISTRY AND ISOTOPIC CHARACTERISTICS OF THE SHOSHONITIC PLUTONIC ROCKS FROM MARONIA AREA, WEST THRACE, GREECE
}

\author{
L. PAPADOPOULOU ${ }^{1}$, G. CHRISTOFIDES ${ }^{1}$, M. BRÖCKER ${ }^{2}$, A. KORONEOS ${ }^{1}$, \\ T. SOLDATOS ${ }^{1}$, G. ELEFTHERIADIS
}

\begin{abstract}
The Maronia pluton, a high-K intrusion in the Circum Rhodope Belt, comprises gabbro to monzonite to granite having pyroxene, biotite and less olivine and amphibole. Three rock groups have been recognised: a basic, an intermediate and an acid. Major, trace and REE geochemistry as well as $\mathrm{Sr}$ and $\mathrm{O}$ isotopes support a genetic relation between the basic and the intermediate group but not between them and the acid group. An AFC process with a carbonate assimilant or an MFC process, where the basic end-member is represented by the less evolved samples, and the acid end-member by more evolved samples having $\mathrm{Sr}$ isotopes higher than those in the acid group, is suggested for the evolution of the basic-intermediate group. The basic-intermediate group originates from a lithospheric mantle while the acid group probably from a low-Sr isotopes crustal melt.
\end{abstract}

KEY WORDS: Maronia plutonic rocks, Greece, High-K, geochemistry, Sr and O isotopes, petrogenesis

\section{INTRODUCTION}

Plutonic rocks ranging in composition from gabbro to granite are widespread in the province of Thrace in northern Greece, intruding the Circum Rhodope Belt. Magmatism in this area is considered to be of broadly Tertiary age. The youngest intrusion is the Maronia pluton (SIDERIS, 1975; KYRIAKOPOULOS, 1987; DEL MORO et al., 1988).

This work, which is a part of the first author's Ph.D. thesis in progress, presents new petrologic, geochemical and isotopic data for the Maronia pluton, aiming to a better understanding of its origin and evolution.

\section{GEOLOGICAL SETTING - PETROGRAPHY}

The Maronia pluton is situated south of Komotini town, in southwest Thrace (Fig. 1) intruding the Circum Rhodope Belt.

The Circum Rhodope Belt is divided into two units: the Makri unit (also known as the phyllite series) and the overlying Drimos-Melia unit (KOURIS, 1980; PAPADOPOULOS, 1982; IOANNIDIS et al., 1998). RICOU et al. (1998) rejected the concept of the Circum Rhodope Belt being a Mesozoic cover of the Rhodope Massif. Instead, they accept the idea that its rocks belong to two distinct greenschists belts. To the west the Maronia pluton intrudes marbles and calc-phyllites of the metasedimentary series of the Makri unit while to the east it intrudes a metamorphic sequence, comprised mostly of phyllites, greenschists and gneisses of the overlying metavolcanosedimentary series of the same unit. The intrusion caused thermal metamorphism in the country rocks (DORYPHOROS, 1990; MPOSKOS \& DORYPHOROS, 1993). The pluton was emplaced during the Oligocene and is considered to be the youngest of the Tertiary plutons that intrude Western Thrace (DEL MORO et al., 1988 and our results).

Based on the Q'/ANOR classification diagram (STRECKEISEN \& LE MAITRE, 1979) (not shown), three main rock groups can be distinguished in the Maronia pluton: a)the basic, b)the intermediate and c)the acid group.

a) The basic group is composed of gabbro $(\mathrm{Gb})$, a dark-coloured, medium-grained rock, having plagioclase, clinopyroxene, red-brown biotite and Fe-Ti oxides and apatite as accessory minerals. Orthopyroxene and olivine are very rare. Interstitial feldspar is also present.

b) The intermediate group is composed of monzonite (Mz), quartz monzonite (QMz), monzogabbro (Mzgb), quartz monzogabbro (QMzgb) and mafic microgranular enclaves (MME).

$\mathrm{Mz}$ shifts to $\mathrm{QMz}$ with an increase of interstitial quartz up to $6 \mathrm{vol} \%$. These rocks are fine- to mediumgrained with monzonitic texture. They consist of plagioclase, clinopyroxene, orthopyroxene, hornblende, redbrown biotite, orthoclase and Fe-Ti oxides and apatite as accessory minerals. Non-perthitic orthoclase encloses poikilitically plagioclase, biotite, orthopyroxene, clinopyroxene and Fe-Ti oxides. Patches of a second genera-

1. Department of Mineralogy, Petrology and Economic Geology, Aristotle University of Thessaloniki, 54006 Thessaloniki, Macedonia, Greece 2. Institut für Mineralogie, Correns Str. 24, 48149 Münster, Germany 


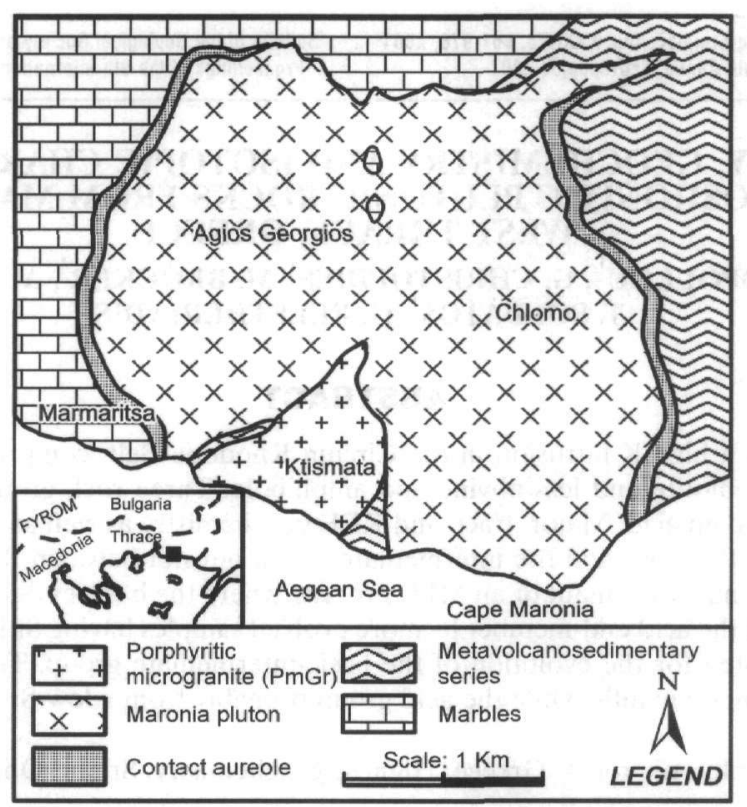

Fig. 1. Petrological map of the Maronia pluton

tion of K-feldspar is often recognised in the poikilitic K-feldspar. Biotite often encloses grains of accessory minerals as well as orthopyroxene and clinopyroxene. The latter is the most abundant pyroxene. Pinkish orthopyroxene is often altered to uralite. It is partially enclosed by either biotite or clinopyroxene and it seems to be the first mineral to crystallize. Hornblende, wherever present, occurs both as primary crystals and as an alteration product of pyroxenes.

Mzgb grades into QMzgb with a small increase of interstitial quartz. Both rocks are coarse- to mediumgrained and contain the same mineral phases as in the case of Mz. Here the K-feldspar occupies the interstitial space between plagioclase and the ferromagnesian minerals, whereas the previously described second K-feldspar generation is missing. Orthopyroxene is more abundant than in the other rock types. Hornblende exists in smaller amounts. From Mzgb to Mz, an antipathetic relation seems to exist between orthopyroxene and amphibole and orthoclase.

The MME, classified as monzogabbro, are fine-grained, consisting of strongly zoned plagioclase phenocrysts, biotite, amphibole, quartz and a few remnants of clinopyroxene phenocrysts, with smaller crystals of orthoclase, epidote and magnetite.

c) The acid group consists of granite (Gr), aplitic dykes and porphyritic micro-granite (PmGr).

$\mathrm{Gr}$ in the form of dykes, $(0.5 \mathrm{~m}$ to a few metres thick) is a fine-grained rock having quartz, $\mathrm{K}$-feldspar, plagioclase, biotite and a few accessory minerals (epidote, allanite, apatite and zircon).

PmGr consists mainly of quartz and perthitic K-feldspar phenocrysts, few plagioclase phenocrysts and few microphenocrysts of biotite set in a medium-grained groundmass of quartz, K-feldspar and plagioclase (see also SIDERIS, 1975). It is strongly altered, tectonised and contains porphyry copper mineralization (MELFOS, 1995).

The relationships between the petrographic types are not always clear. Few small exposures of Gb have been found near the center of the plutonic body. No clear relation between $\mathrm{Gb}$ and the rocks of the intermediate group was found. At the southern area the PmGr intrudes the Maronia pluton and the metamorphic basement. The Gr and the aplitic dykes intrude the rocks of the intermediate group. MME are mostly found in the intermediate group. They have round to ellipsoidal and sometimes irregular forms and range in size from less than $5 \mathrm{~cm}$ to about $30 \mathrm{~cm}$. Finally, scattered blocks of the basement are enclosed by the rocks of the intermediate group. They are irregular in shape and their size ranges from $5-20 \mathrm{~cm}$. The schistosity of the basement rocks is still recognisable.

\section{MINERALOGY}

Orthopyroxene, is a Mg-rich $(\mathrm{Mg} /(\mathrm{Mg}+\mathrm{Fe})=0.55-0.77)$ enstatite (MORIMOTO, 1989) with an average composition $\mathrm{En}_{0.63} \mathrm{Fs}_{0.36} \mathrm{Wo}_{0.01}$. Clinopyroxene is augite and compared to orthopyroxene its $\mathrm{Mg} /(\mathrm{Mg}+\mathrm{Fe})$ values are 


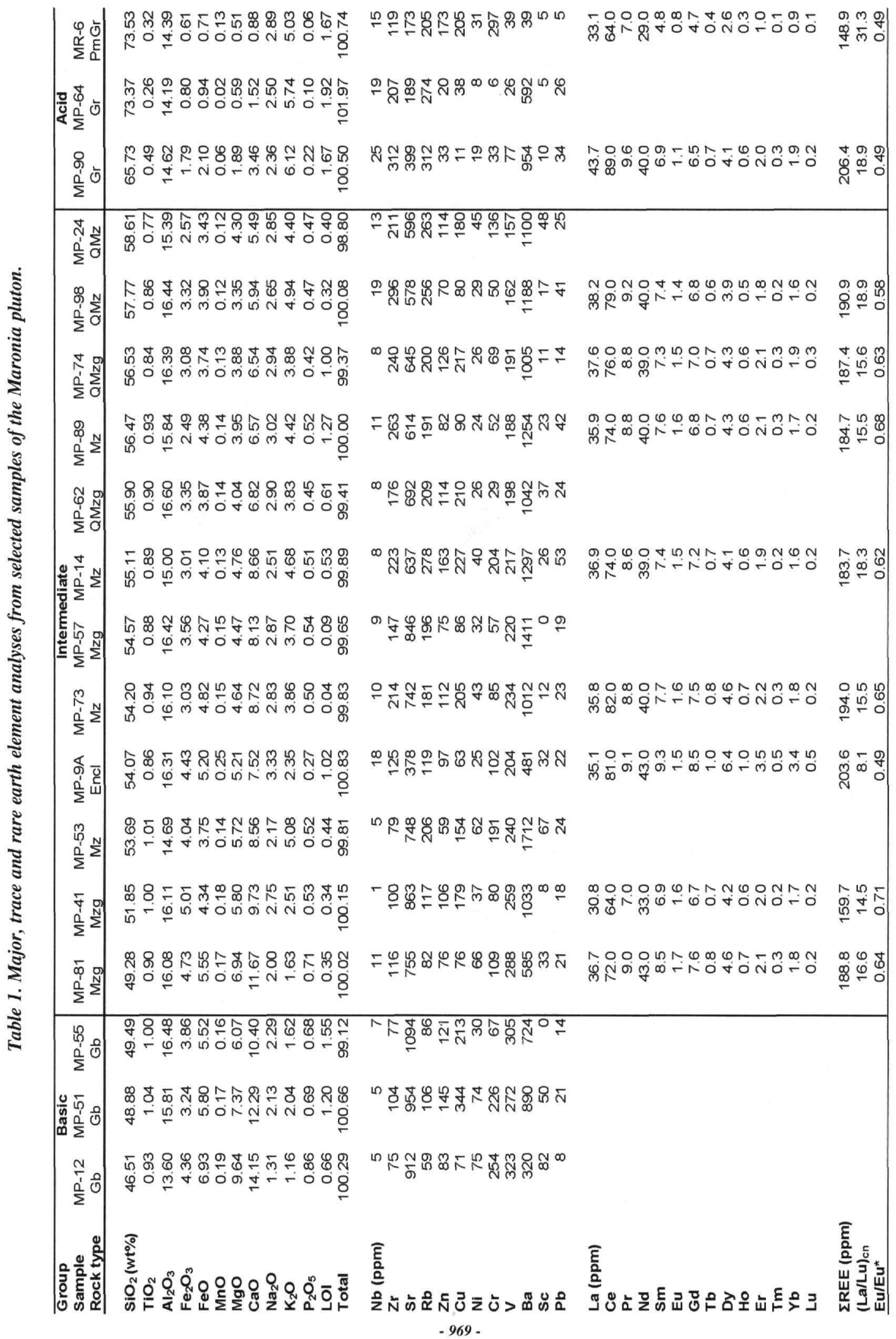


slightly higher (0.64-0.84). Its average composition is $\mathrm{En}_{0.43} \mathrm{Fs}_{0.15} \mathrm{Wo}_{0.41}$. Both pyroxenes generally show decreasing $\mathrm{Mg} /(\mathrm{Mg}+\mathrm{Fe})$ ratio from $\mathrm{Gb}$ to $\mathrm{QMz}$.

Amphibole is a magnesiohornblende (LEAKE et al., 1997) with $\mathrm{Mg} /(\mathrm{Mg}+\mathrm{Fe})=0.69$ to 0.91 occurring as a primary phase in a few samples of $\mathrm{Mz}$ and Mzgb. Actinolite, resulting from the breakdown of pyroxene also exists.

Biotite has a $\mathrm{Fe} /(\mathrm{Fe}+\mathrm{Mg}$ ) ratio from 0.123 to 0.501 in the basic and intermediate group. It is Ti-rich (up to $6.5 \mathrm{wt} \%$ in $\left.\mathrm{TiO}_{2}\right)$ and has little or no ${ }^{\left[{ }^{[6}\right.} \mathrm{Al}$. In the acid group $\mathrm{Fe} /(\mathrm{Fe}+\mathrm{Mg})=0.271$ and $\mathrm{TiO}_{2}$ reaches the value of $3.6 \mathrm{wt} \%$.

Plagioclase is present in all rock types. In the optically zoned crystals the core composition ranges from $\mathrm{An}_{54}$ to $\mathrm{An}_{78}$ where as in the unzoned antiperthitic crystals the overall composition ranges from $\mathrm{An}_{35}$ to $\mathrm{An}_{48}$. $\mathrm{Zoning}$ is either normal or oscillatory. The Or content is $0.69-2.55 \mathrm{~mol} \%$. In the acid group plagioclase has a composition of oligoclase $\left(\mathrm{Ab}_{70} \mathrm{An}_{27} \mathrm{Or}_{3}\right)$.

$\mathrm{K}$-feldspar ranges in composition from $\mathrm{Or}_{70}$ to $\mathrm{Or}_{85}$ The non-perthitic major $\mathrm{K}$-feldspar phase contains small amounts of $\mathrm{BaO}(<1 \mathrm{wt} \%)$. The other phase occurring as patches in the previous one, contains $\mathrm{BaO}$ up to $3.5 \mathrm{wt} \%$. The $K$-feldspar in the acid group has a composition of $\mathrm{Or}_{90} A b_{10} A n_{\sigma}$.
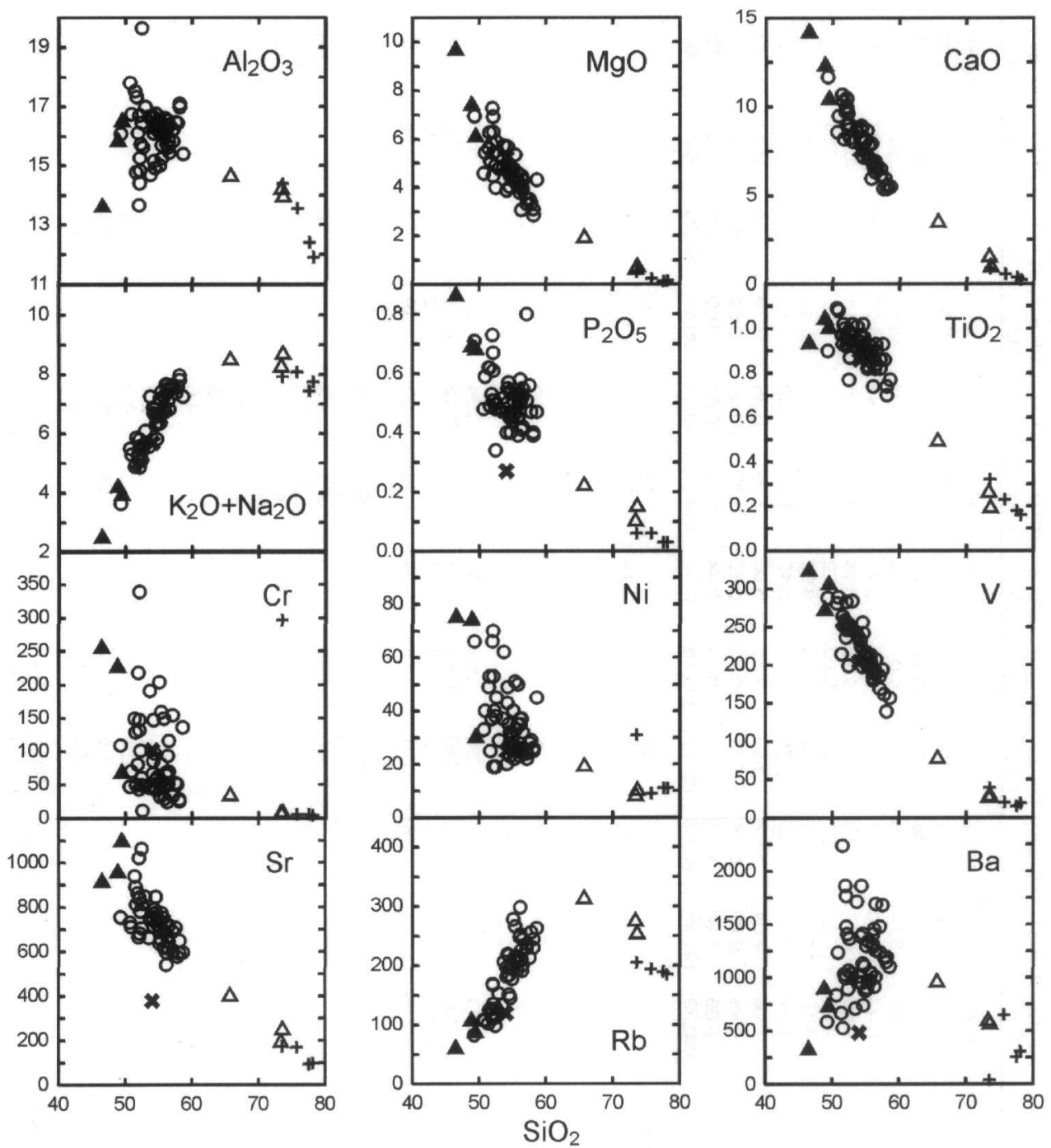

Fig. 2. Major (wt $\frac{\rho}{8}$ ) and trace (ppm) element vs SiO2 variation diagrams of the Maronia pluton. $\boldsymbol{\Delta}$ basic; $O$ intermediate; $\Delta$ acid $(\mathrm{Gr}) ;+$ acid (PmGr); $\mathbf{X} M M E$ 
All rock types generally contain magnetite and in a few cases, ilmenite.

\section{GEOCHEMISTRY}

Representative samples from the plutonic and basement rocks were analysed for major, trace elements and REE. The analyses are shown in Table 1, and the compositional variations are depicted in figures 2 and 3.

\section{Major elements}

Basic group: $\mathrm{SiO}_{2}$ ranges from $46.5 \mathrm{wt} \%$ to $49.5 \mathrm{wt} \%$. Most of the other elements $(\mathrm{FeO}, \mathrm{MgO}, \mathrm{CaO}, \mathrm{MnO}$ and $\mathrm{P}_{2} \mathrm{O}_{5}$ ) decrease with $\mathrm{SiO}_{2}, \mathrm{TiO}_{2}$ is rather constant and $\mathrm{Al}_{2} \mathrm{O}_{3}, \mathrm{Na}_{2} \mathrm{O}$ and $\mathrm{K}_{2} \mathrm{O}$ increase.

Intermediate group: $\mathrm{SiO}_{2}$ ranges from $49.3 \mathrm{wt} \%$ to $58.6 \mathrm{wt} \%$. The behaviour of all the oxides of the intermediate group is the same as in the basic group, except $\mathrm{Al}_{2} \mathrm{O}_{3}$ and $\mathrm{TiO}_{2}$, which decrease and remains rather constant respectively.

Acid group: $\mathrm{SiO}_{2}$ ranges from $73.4 \mathrm{wt} \%$ to $78.1 \mathrm{wt} \%$ with one sample having $65.7 \mathrm{wt} \%$. A compositional gap between the intermediate and the acid groups is obvious. This is not the result of insufficient sampling. Most of the major elements decrease with silica content while alkalies are constant.

The analysed samples of basic and intermediate groups are metaluminous, while the members of the acid group are peraluminous. The Maronia rocks show a calc-alkaline affinity based on their AFM composition. On the diagram of PECCERILLO \& TAYLOR (1976) (not shown) the majority of rocks plot in the shoshonitic field. The Maronia rocks have low and relatively constant $\mathrm{FeO}^{*} / \mathrm{MgO}$ ratio and high $\mathrm{K}_{2} \mathrm{O}$ and $\mathrm{P}_{2} \mathrm{O}_{5}$ abundances. The low $\mathrm{FeO}^{*} / \mathrm{MgO}$ ratio seems to be a general characteristic of monzonite suites with hornblende and $\mathrm{Mg}$-rich

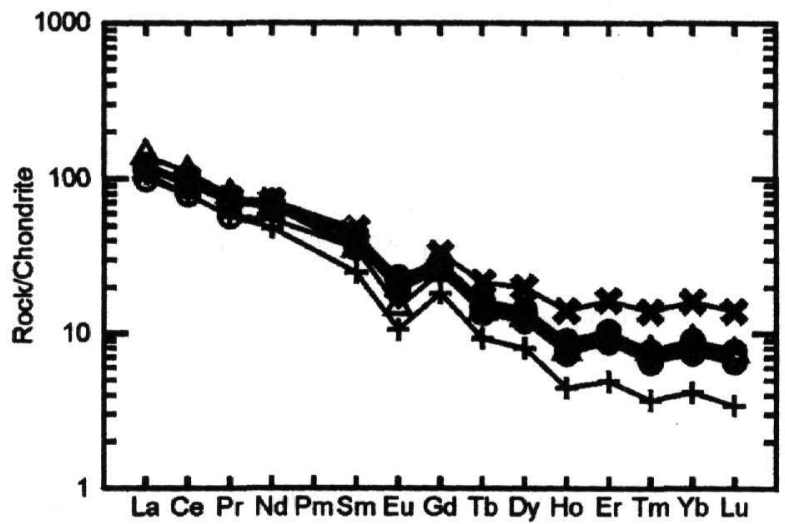

Fig. 3. Chondrite-normalized REE patterns of selected samples of the Maronia pluton. Normalization factors after Boynton (1984). Symbols as in figure 2.
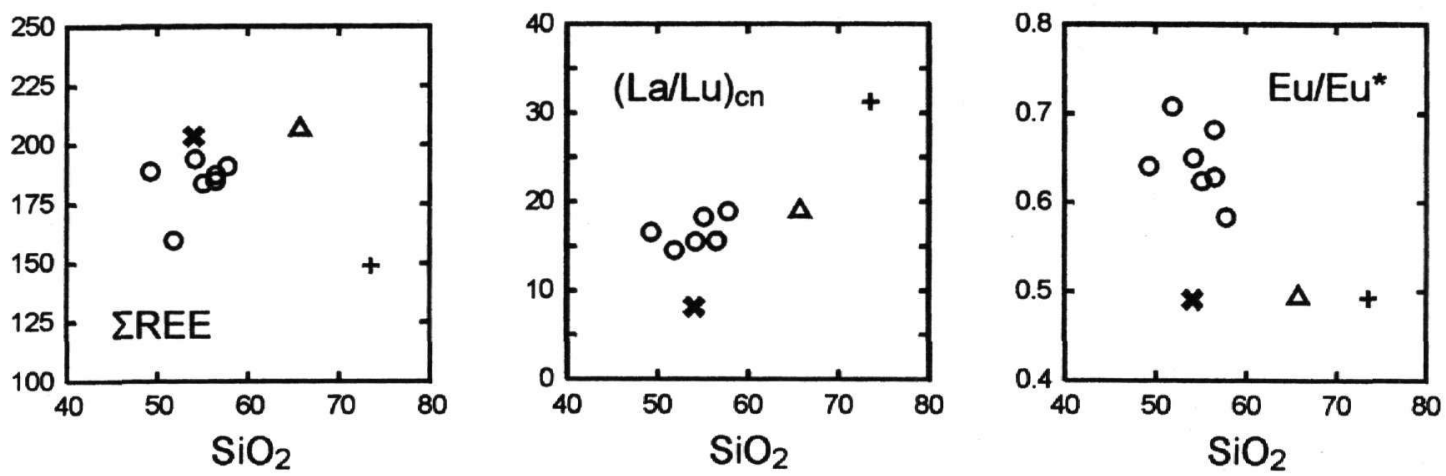

Fig. 4. $\mathrm{SiO}_{2}$ vs $\Sigma \mathrm{REE},(\mathrm{La} / \mathrm{Lu})_{c n}$ and Eu/Eu* variation diagrams for selected samples of the Maronia pluton pluton. Symbols as in figure 2. 
biotite, as well as of Andean shoshonites, which also show high $\mathrm{P}_{2} \mathrm{O}_{5}$ (RAPELA \& PANKHURST, 1996).

\section{Trace elements}

Basic group: In the basic group $\mathrm{Rb}, \mathrm{Ba}, \mathrm{Cu}, \mathrm{Zn}, \mathrm{Ce}, \mathrm{Pb}$, Ta, Th and $\mathrm{Hf}$ increase with $\mathrm{SiO}_{2}$ while $\mathrm{Ni}, \mathrm{Cr}, \mathrm{V}$ and $\mathrm{Sc}$ decrease. $\mathrm{Sr}, \mathrm{Nb}, \mathrm{Zr}$ and $\mathrm{Nd}$ remain rather constant while $\mathrm{La}$ and $\mathrm{U}$ are highly scattered.

Intermediate group: Trace elements in this group show the same geochemical behaviour as the basic group with the exception of $\mathrm{Sr}, \mathrm{Cu}, \mathrm{Ga}, \mathrm{Co}$ and $\mathrm{Ta}$ which decrease with silica. $\mathrm{Zr}$ and $\mathrm{U}$ increase with silica content while $\mathrm{Nb}, \mathrm{Zn}, \mathrm{Nd}$ and $\mathrm{Sc}$ are highly scattered.

Acid group: Most trace elements show a different tendency compared to the two former rock groups. $\mathrm{Rb}, \mathrm{Ba}$, $\mathrm{Sr}, \mathrm{Nb}, \mathrm{Zr}, \mathrm{Ni}, \mathrm{Cr}, \mathrm{Zn}, \mathrm{V}$ and $\mathrm{Ga}$ decrease while $\mathrm{Cu}$ and $\mathrm{Pb}$ increase with silica. Sc remains constant. Co appears to decrease with silica but has the highest values in the PmGr.

\section{$R E E$}

Chondrite-normalized REE patterns of 10 selected samples from all the rock groups are given in figure 3. The resulting patterns are very similar showing a slight LREE enrichment relative to HREE. Particularly, La/ $\mathrm{Lu}_{\mathrm{cn}}$ is 16.6 in the basic group, 14.5-18.9 in the intermediate group (7.0 for the MME) and 18.9-31.2 in the acid group. The Maronia rocks show small Eu anomalies (Eu/Eu*), as found in other shoshonites (PE-PIPER, 1980). $\mathrm{Eu} / \mathrm{Eu}^{*}$ varies between 0.75 in the basic group, $0.59-0.72$ in the intermediate group and $0.49-0.50$ in the acid group.

The MME has slightly higher $\Sigma$ REE values and lower $(\mathrm{La} / \mathrm{Lu})_{\mathrm{CN}}$ and $\mathrm{Eu} / \mathrm{Eu}^{*}$ compared to the other intermediate rocks (Fig. 4). The PmGr differs markedly from $\mathrm{Gr}$ in the sense of $(\mathrm{La} / \mathrm{Lu})_{\mathrm{CN}}$ and $\Sigma \mathrm{REE}$. $(\mathrm{La} / \mathrm{Lu})_{\mathrm{CN}}$ and $\Sigma$ REE increase slightly while $\mathrm{Eu} / \mathrm{Eu}^{*}$ increases with silica content from the basic to the intermediate group and then decreases in the intermediate group to the Gr of the acid group.

\section{ISOTOPIC DATA - AGE}

Based on petrological characteristics, 15 samples were selected and analysed for $\mathrm{Sr}$ and $\mathrm{O}$ isotopes. Biotite concentrates of three samples of the intermediate group were analysed by the $\mathrm{Rb} / \mathrm{Sr}$ method. The results are presented in table 2.

$\mathrm{Rb} / \mathrm{Sr}$ whole-rock analyses alone were not able to provide an isochron. In order to determine the age of the pluton two-point isochrons were calculated using the three biotite and corresponding whole-rock samples. Assuming that the closing age of the biotite agrees with the cooling age of the pluton, three ages were found, 29 Ma, 29.3 Ma and 29.4 Ma. These values agree with the 28.7 Ma age given by DEL MORO et al. (1988). We

Table 2. Whole-rock and biotite $\mathrm{Rb}-\mathrm{Sr}$ and whole-rock oxygen isotopic data from selected samples of the Maronia pluton.

\begin{tabular}{|c|c|c|c|c|c|c|c|c|c|}
\hline Sample & Group & $\begin{array}{c}\text { Rb } \\
\text { (ppm) }\end{array}$ & $\begin{array}{c}\text { Sr } \\
(\mathrm{ppm})\end{array}$ & ${ }^{87} \mathrm{Rb} /{ }^{86} \mathrm{Sr}$ & ${ }^{87} \mathrm{Sr} /{ }^{86} \mathrm{Sr}$ & $2 \sigma$ & $\begin{array}{l}\left({ }^{87} \mathrm{Sr} /{ }^{86} \mathrm{Sr}\right) \\
\text { for } 29 \mathrm{Ma}\end{array}$ & Age & $\begin{array}{l}\delta^{18} 0 \\
\left(\%_{\infty 0}\right)\end{array}$ \\
\hline MP-81 & Intermediate & 79.1 & 760.0 & 0.301 & 0.706952 & 0.000020 & 0.706828 & & 7.47 \\
\hline MP-81 (biotite) & Intermediate & 614.5 & 17.5 & 102.051 & 0.748881 & 0.000018 & & $29.0 \mathrm{Ma}$ & \\
\hline $\mathrm{MP}-41$ & Intermediate & 110.7 & 699.0 & 0.458 & 0.706187 & 0.000021 & 0.705998 & & 7.50 \\
\hline MP-53 & Intermediate & 103.2 & 674.8 & 0.443 & 0.707496 & 0.000023 & 0.707314 & & 7.28 \\
\hline MP-9A & Intermediate & 122.4 & 376.9 & 0.940 & 0.706143 & 0.000019 & 0.705756 & & 7.41 \\
\hline MP-73 & Intermediate & 177.8 & 645.7 & 0.796 & 0.706578 & 0.000025 & 0.706250 & & 7.06 \\
\hline MP-57 & Intermediate & 175.8 & 691.9 & 0.735 & 0.707149 & 0.000020 & 0.706846 & & 7.45 \\
\hline MP-14 & Intermediate & 286.9 & 550.1 & 1.509 & 0.707798 & 0.000022 & 0.707176 & & 8.06 \\
\hline MP-14 (biotite) & Intermediate & 1238.7 & 8.8 & 414.550 & 0.879966 & 0.000024 & & $29.3 \mathrm{Ma}$ & \\
\hline MP-62 & Intermediate & 153.3 & 703.0 & 0.631 & 0.706338 & 0.000021 & 0.706078 & & 7.59 \\
\hline MP-62 (biotite) & Intermediate & 777.5 & 12.4 & 183.325 & 0.782408 & 0.000019 & & $29.4 \mathrm{Ma}$ & \\
\hline MP-89 & Intermediate & 189.4 & 603.1 & 0.908 & 0.707265 & 0.000026 & 0.706891 & & 7.35 \\
\hline MP-74 & Intermediate & 175.7 & 653.6 & 0.777 & 0.706315 & 0.000016 & 0.705995 & & 7.96 \\
\hline MP-98 & Intermediate & 228.2 & 525.6 & 1.256 & 0.708275 & 0.000018 & 0.707758 & & 8.29 \\
\hline MP-24 & Intermediate & 244.0 & 492.1 & 1.434 & 0.708337 & 0.000021 & 0.707746 & & 7.99 \\
\hline MP-90 & Acid & 309.8 & 399.8 & 2.242 & 0.708139 & 0.000020 & 0.707216 & & 9.13 \\
\hline MP-64 & Acid & 274.9 & 191.2 & 4.160 & 0.708363 & 0.000023 & 0.706649 & & 11.33 \\
\hline MR-6 & Acid & 207.9 & 174.0 & 3.456 & 0.707897 & 0.000020 & 0.706473 & & 10.13 \\
\hline
\end{tabular}



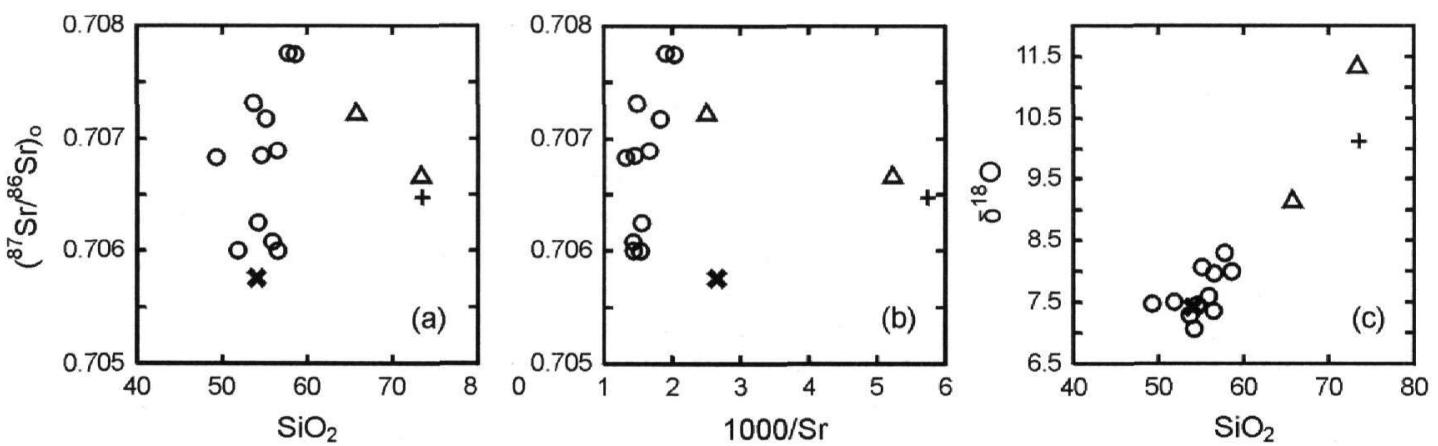

Fig. 5. a) $\left({ }^{8 /} \mathrm{Sr} /{ }^{86} \mathrm{Sr}\right) 。$ vs $\mathrm{SiO}_{2}$, b) $\left({ }^{8 /} \mathrm{Sr} /{ }^{86} \mathrm{Sr}\right) 。 \mathrm{vs} 1000 / \mathrm{Sr}$ and c) $\delta^{18} \mathrm{O} \mathrm{vs} \mathrm{SiO}_{2}$ variation diagrams. Symbols as in figure 2 .

believe that they approximate the emplacement age of the plutonic body, owing to its small size and the shallow intrusion depth.

Accepting a $29 \mathrm{Ma}$ emplacement age for the pluton the ${ }^{87} \mathrm{Sr} /{ }^{86} \mathrm{Sr}$ initial isotopic ratios range from 0.7062 to 0.7077 in the intermediate group with the smallest value $(0.7057)$ belonging to the MME. In the acid group initial isotopic ratios range from 0.7065 to 0.7072 . The $\mathrm{Sr}$ initial isotopic ratios of the analysed samples increase (with steep trend) with $\mathrm{SiO}_{2}$ and $1 / \mathrm{Sr}$ in the intermediate group but decrease in the acid group (Fig. 5a and b).

The $\delta^{18} \mathrm{O}$ value increases with $\mathrm{SiO}_{2}$ from $7.06 \%$ to $8.29 \%$ in the intermediate group and from 9.13 to 11.33 $\%$ in the acid group (Fig. 5c).

\section{DISCUSSION}

Basic - intermediate groups: The existence of a genetic relation between the two groups seems possible as indicated by their geological relationships, mineralogy, major, trace element and REE geochemistry as well as by their isotopic composition. A relation between MME and the other rocks of the intermediate group is not supported by the REE and Sr relations although there are no differences in the rest elements as well as in the isotopes.

The basic - intermediate groups of Maronia are medium to fine-grained rocks with no apparent layering, they lack cumulative textures and rather exhibit heterogranular hypidiomorphic texture. They lack positive Eu
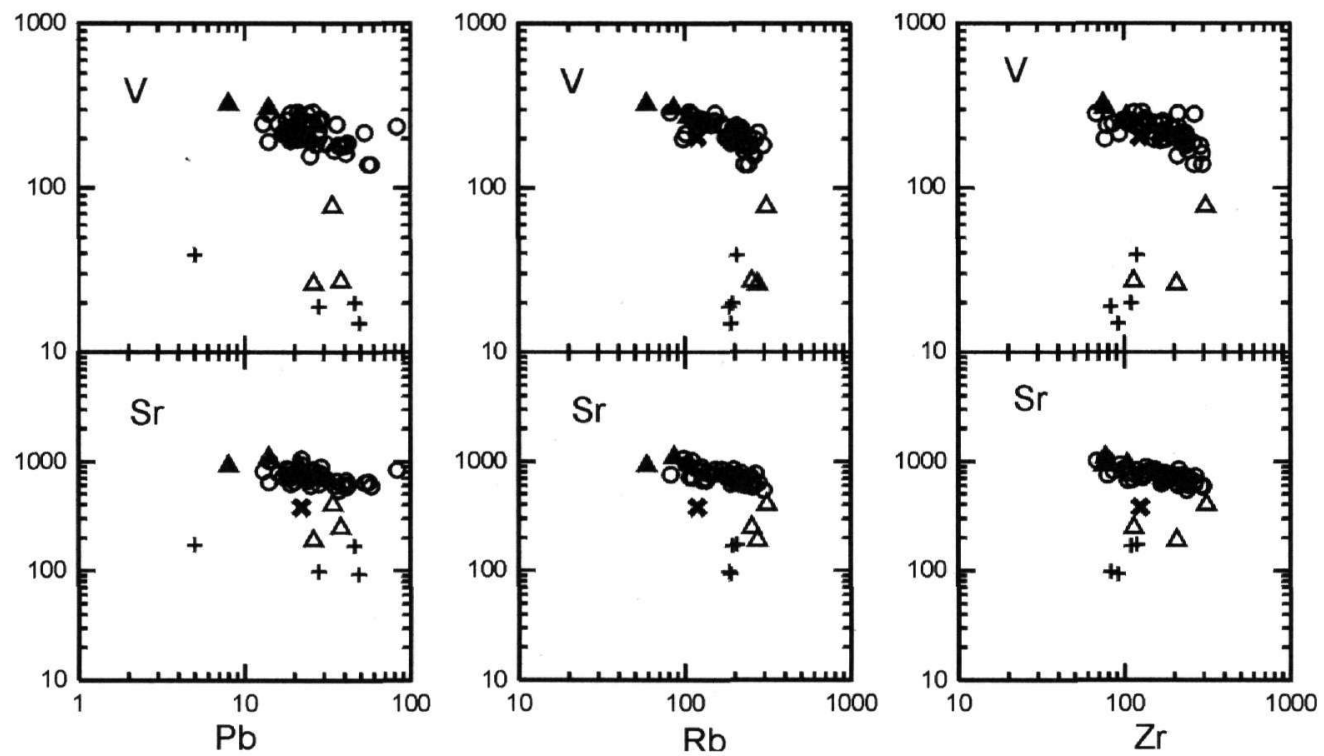

Fig. 6. Compatible vs incoppatible element (ppm) variation diagrams of the Maronia pluton. Symbols as in figure 2. 
anomalies and have high incompatible element contents. These rocks may thus be considered to represent near liquid compositions rather than cumulates.

The isotopic $\mathrm{O}$ and $\mathrm{Sr}$ variations in the basic - intermediate groups as well as the continous trends in the Harker diagrams, suggest an open-system evolution process. This could be: a. assimilation - fractional crystallization (AFC), b. mixing or c. mixing - fractional crystallization (MFC). Since, however, only few high correllation coefficients exist between the major and trace elements and between trace elements, although high correllation coefficients exist between major elements, a simple mixing of two magmas with slightly different isotopic characteristics is ruled out. This conclusion is supported from the linear trends in log-log diagrams of compatible vs incompatible elements (Fig. 6) as well as from the marked changes in composition of the primary mineral phases (eg. pyroxenes). On the contrary an MFC process is more plausible, supported also from the existence in the $\mathrm{QMz}$ of MME with more basic composition than the host rock. Regarding the Sr isotopic composition, the less evolved Mzgb samples or the MME represent the more mafic magma - end member of this procedure with $\left({ }^{87} \mathrm{Sr} /\right.$ $\left.{ }^{86} \mathrm{Sr}\right)_{0}=0.70576-0.70599$ while the acid end member must be characterized by $\left({ }^{87} \mathrm{Sr} /{ }^{86} \mathrm{Sr}\right)_{0}$ higher than that of the QMz $(0.70775-0.70776)$. This implies that the acid group with $\left({ }^{87} \mathrm{Sr} /{ }^{86} \mathrm{Sr}\right)_{0}$ lower than 0.70722 could not represent the acid end member.

An alternative is a process of fractional crystallization plus assimilation of host crustal rocks. Such a process, which is supported by the log-log trace element diagram trends, could intensively increase the $\mathrm{Sr}$ isotopes. Moreover, if the assimilant was a carbonate, the AFC process would have resulted in an intense increase of the $\mathrm{Sr}$ isotopes but at the same time in a less, than the expected, due to plagioclase fractionation, decrease of strontium. The assimillation of a particularly Sr-rich material (carbonate) would tend to increase the $\mathrm{Sr}$ abundance in the melt. To document such a hypothesis, the isotopic composition of the country carbonate rocks is needed which, however, is not available at the moment.

In any case it is obvious from the major and trace element compositional trends as well as from the isotopes that fractional crystallization, either as AFC or MFC, has played a major role in the evolution of the basicintermediate rocks of the Maronia pluton. However, taking into account the scattering of some trace elements for the same $\mathrm{SiO}_{2}$ content in the basic-intermediate group, an unmixing process, where the crystallizing solid phases have not been separated completely from the residual liquid resulting in rocks consisting of mixtures of early crystallizing phases and intercumulus melts (McCARTHY and HASTY 1976; SULTAN et al. 1986; SAWKA 1988; POLI and TOMMASINI 1991), could be operative.

The variation in major and trace elements suggests that plagioclase was the major fractionating phase during magmatic evolution (decrease of $\mathrm{Sr}$; the small negative Eu anomalies may reflect combined fractionation of plagioclase \pm pyroxene \pm horneblende). Pyroxene played an important role during the stage from $\mathrm{Gb}$ to $\mathrm{Mzgb}$ (increasing $\mathrm{Al}_{2} \mathrm{O}_{3}$ and decreasing $\mathrm{CaO}$ and $\mathrm{MgO}$ with increasing $\mathrm{SiO}_{2}$ ). Olivine probably crystallized in the first stage of fractionation. Fe-Ti oxide minerals and apatite were also fractionating, as documented by the decrease of $\mathrm{V}, \mathrm{TiO}_{2}$ and $\mathrm{P}_{2} \mathrm{O}_{5}$ respectively with increasing $\mathrm{SiO}_{2} . \mathrm{K}_{2} \mathrm{O}, \mathrm{Rb}$ and $\mathrm{Ba}$ increase reflects the minor role of biotite and $\mathrm{K}$-feldspar fractionation.

The composition of the source region and the parental magma of the Maronia basic to intermediate groups

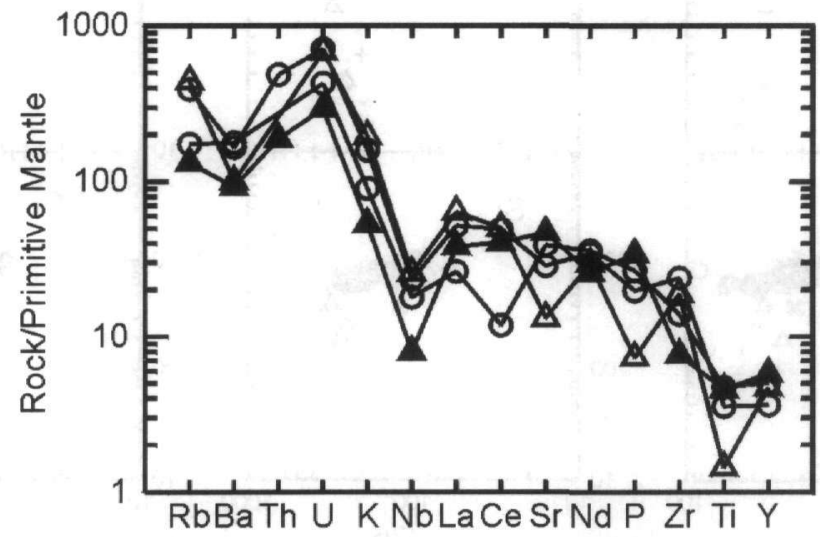

Fig. 7. Primitive mantle-normalised trce element diagram of selected samples of the Maronia pluton. normalisation factors after Sun \& McDonough (1989). Symbols as in figure 2. 
can be approached from the most mafic rocks. The elevated, relative to mantle, $\mathrm{Sr}$ isotopes of these rocks indicate that they could be either the result of mixing between a depleted asthenospheric mantle and a crustal component or alternatively that these isotopic characteristics are primary which rather point to a source region in the continental lithospheric mantle or mafic lower crust. The high amount of a crustal component required for the asthenospheric component to reach the isotopic composition of the more basic rocks is inconsistent with the low $\mathrm{SiO}_{2}$ and high $\mathrm{MgO}$ contents. The high $\mathrm{Sr}$ concentration and $\mathrm{Mg}$ numbers $(0.55-0.61)$ of these rocks are not consistent with their derivation from mafic lower continental crust $(\mathrm{Mg}$ number $=0.51)$ (TAYLOR \& McLENNAN, 1985). Their Nb and Ti negative anomalies as well as the LILE enriched composition (Fig. 7) indicate that the source of these rocks would rather be a LILE- and LREE-enriched continental lithospheric mantle.

In the case where the evolution process is $\mathrm{MFC}$, the acid member, represented by the more evolved $\mathrm{QMz}$ (with $\mathrm{SiO}_{2}=57.8-58.6, \mathrm{Sr}=578-649, \mathrm{Mg}$ number=0.44-0.57) is probably the result of partial melting of an isotopically different continental lithospheric mantle or a mafic lower crust since the crust isotopic ratios in the area could be relatively low (see acid group).

Acid group: A genetic relation between the intermediate and acid group seems at first sight possible as indicated by the $\mathrm{Sr}$ initial isotopic ratios, major and most of the trace element variation diagrams and the REE behaviour since the changes in the behaviour of some major and trace elements could be the result of change in the fractionating assemblage. The elevated $\delta^{18} \mathrm{O}$ value of the less evolved $\mathrm{Gr}$ sample compared to the more evolved intermediate sample can be also the result of a simple fractionation procces, since the fractional crystallisation can increase $\delta^{18} \mathrm{O}$ up to $1 \%$. On the other hand any genetic relation between the intermediate and acid group is ruled out by their geological relationship as well as by the $\mathrm{SiO}_{2}$, $\mathrm{Sr}$ and $\mathrm{V}$ compositional gaps.

The differences in REE and Co content between Gr and PmGr rule out a genetic relation between them, although it is supported by the other elements and isotopes.

Since the acid group is not the result of differentiation of the more evolved intermediate group magma, its isotopic signatures are primary. The elevated $\delta^{18} \mathrm{O}$ values support partial melting of a crustal source which supports the hypothesis that the crust in the area is characterized by relatively low $\mathrm{Sr}$ isotopic values.

\section{ANALYTICAL METHODS}

Whole rock major and trace elements have been analysed by XRF using pressed pellets and fused disks at the Institute of Petrology, University of Vienna, Austria. Microprobe analyses were carried out by a JEOL JSM 840-A scanning electron microscope at the Aristotle University of Thessaloniki, Greece. Natural and synthetic mineral standards were used. REE were obtained by INAA at the Department of Geology, Saint Mary's University, Halifax, Canada. Whole rock samples and biotite concentrates were analysed with the $\mathrm{Rb} / \mathrm{Sr}$ method in the Zentrallaboratorium fór Geochronologie, Mónster, Germany. For analytical details see Brpcker and Franz (1998). Oxygen isotope analyses were carried out at the Institute of Earth Sciences, Hebrew University of Jerusalem, Israel.

\section{ACKNOWLEDGEMENTS}

We would like to express our special thanks to G. Pe-Piper, K. Petrakakis and A. Matthews for helping to obtain REE, XRF and oxygen isotope analyses respectively. We also thank E. Pavlidou for assistance in microprobe mineral analyses.

\section{REFERENCES}

BOYNTON, V. W. (1984). Geochemistry of the rare earth elements: Meteorite studies. In: Henderson P. (ed.), Rare earth element geochemistry. Elsevier, 63-114.

BRÖCKER, M., AND FRANZ, L. (1998). Rb-Sr isotope studies on Tinos Island (Cyclades, Greece): additional time constraints for metamorphism, extent of infiltration-controlled overprinting and deformational history. Geol. Mag., 135, 369-382.

DEL MORO, A., INNOCENTI, F., KYRIAKOPOUlOS, C., MANETTI, P. and PAPADOPOULOS, P. (1988): Tertiary granitoids from Thrace (Northern Greece): Sr isotopic and petrochemical data. N. Jb. Miner. Abh., 159, 113-135.

DORYPHOROS, K. (1990). The Maronia pluton and its metamorphic effects on the surrounding rocks of the Makri series. Ph. D. Thesis, National Technical University of Athens, 166pp. (in Greek with English abstract).

IOANNIDIS, N., CHATZIDIMITRIADIS, E., MOUNTRAKIS, D. and KILIAS, A. (1998). Study of metasedimentary 
formations of Upper Palaeozoic to Meozoic age, from Nea Makri (Alexandroupolis area), W. Thrace/Greece. Bull. Geol. Soc. Greece, XXXII/3, 79-89.

KOURIS, C. (1980). Geological map of Greece, Mesi-Xilagani sheet, scale 1:50000, IGME, Athens.

KYRIAKOPOULOS, C. (1987). Geochronological, geochemical, mineralogical and isotopic studies of the Tertiary plutonic rocks of the Rhodope. Ph. D. Thesis, Univ. of Athens, 343pp. (in Greek with English abstract).

LEAKE, B. E., WOOLLEY, A. R., ARPS, C. E. S., BIRCH, W. D., GILBERT, M. C., GRICE, J. D., HAWTHORNE, F. C., KATO, A., KISCH, H. J., KRIVOVICHEV, V. G., LINTHOUT, K., LAIRD, J., MANDARINO, J. A., MARESCH, W. V., NICKEL, E. H., ROCK, N. M. S., SCHUMACHER, J. C., SMITH, D. C., STEPHENSON, N. C. N., UNGARETTI, L., WHITTAKER, E. J. W. \& YOUZHI, G. (1997). Nomenclature of amphiboles. Report of the Subcommittee on Amphiboles of the International Mineralogical Association Commission on New Minerals and Mineral Names. Can. Mineral., 35, 219-246.

McCARTHY, T. S., and HASTY, R. A. (19'/6). Trace element distribution patterns and their relationship to the crystallization of granitic melts. Geochim. Cosmochim. Acta, 40, 1351-1358.

MELFOS, B. (1995). Investigations of the base and precious metals of the Circum Rhodope Belt in Thrace. Ph.D. Thesis, Arist. Univ. of Thessaloniki, 289pp. (in Greek with English abstract).

MPOSKOS, E. and DORYPHOROS, K. (1993). High temerature Skarns in the Maronia area (NE Greece). Bull. Geol. Soc. Greece, XXVIII/2, 23-35.

MORIMOTO, N. (1989): Nomenclature of pyroxenes. Can. Mineral., 27, 143-156

PAPADOPOULOS, P. (1982). Geological map of Greece, Maronia sheet, scale 1:50000, IGME, Athens.

PECCERILLO, A. and TAYLOR, S. R. (1976). Geochemistry of Eocene calc-alkaline volcanic rocks from the Kastamonu area, northern Turkey. Contrib. Mineral. Petrol., 58, 63-81.

PE-PIPER, G. (1980). Geochemistry of Miocene Shoshonites, Lesbos, Greece. Contrib. Mineral Petrol., 72, 387-96.

POLI, G., and TOMMASINI, S. (1991). A geochemical approach to the evolution of granitic plutons: a case study, the acid intrusions of Punta Falcone (northern Sardinia, Italy). Chem. Geol., 92, 87-105.

RAPELA, C. W. and PANKHURST, R. J. (1996). Monzonite suites: the innermost Cordilleran plutonism of Patagonia. Earth Sciences, 87, 193-203.

RICOU, L. -E., BURG, J. -P.,GODFRIAUX, I. and IVANOV, Z. (1998). Rhodope and Vardar: the metamorphic and the olistostromic paired belts related to the Cretaceous subduction under Europe. Geodinamica Acta, 11, 6, 285309.

SAWKA, W. N. (1988). REE and trace element variation in accessory minerals and hornblende from the strongly zoned McMurry Meadows Pluton. California. Trans. R. Soc. Edinburgh Earth Sci., 79, 157-168.

SIDERIS, K. (1975). Investigation of characteristic features in plutonic and volcanic rocks of the East Rhodope Zone: relationships between volcanic and plutonic activity. Lecturer Thesis, Univ. of Athens, 108pp. (in Greek).

STRECKEISEN,A. and LE MAITRE, R. WA. (1979). A Chemical Approximation To The Modal QAPF Classification Of The Igneous Rocks. N. Jb. Miner. Abh., 136/2, 169-206.

SULTAN, M., BATIZA, R. and STURCHIO, N. C. (1986). The origin of small-scale geochemical mineralogic variations in a granite intrusion. A crystallization and mixing model. Contib. Mineral. Petrol., 93, 513-523.

SUN, S., McDONOUGH, W. F. (1989).Chemical and isotopic systematics of oceanic basalts: implications for mantle composition and processes. In: Saunders, A. D., Norry, M. J. (Eds.), Magmatism in the ocean basins, Geol. Soc. (Spec. Publ.), London, 42, 313-345.

TAYLOR, S. R. and McLENNAN, S. M. (1985). The Continental Crust: Its composition and evolution. Blackwell, Oxford, 312pp. 